\title{
Features of the Kabardians' vernacular architecture in the 19th - early 20th centuries
}

\author{
Fatima Kanokova* \\ Kabardino-Balkarian State University named after Kh.M. Berbekov, 360004, Nalchik, Russia
}

\begin{abstract}
The study examines the vernacular architecture features of the Kabardians in the 19th - early 20th centuries. The main types of dwellings, that are characteristic of the ethnos in the indicated period, are distinguished - these are single-chamber and multi-chamber tourluch houses - huts. The techniques and materials used in their construction are described. The features of the internal space space-planning solutions for each type of dwelling, the presence of a hearth, its sacred function, gender signs of zoning, as well as the principles of organizing the estate space as a whole are revealed.
\end{abstract}

\section{Introduction}

The vernacular architecture of the ethnic groups inhabiting the North Caucasus has its own individual characteristics that allow us to judge the creative thought development of the folk architects who created it. Everything, from the material and construction technology to the space-planning solution, reflects the various stages of the life of this or that nation, its worldview, moral and aesthetic values.

Within the framework of this study, special attention will be paid to the problem of identifying the vernacular architecture features of the Kabardians in the chronological framework of the 19th - early 20th centuries. Kabardians are one of the sub-ethnic of a large group of peoples of the North Caucasus - the Adygs. For many centuries they have been improving their house-building technologies related to tourluch construction. During the period under review, while remaining true to folk traditions, the Kabardians, on the basis of a single-chamber house, created an original type of multi-chamber "long house" that preserved all the ethnic vernacular architecture elements.

\section{Literature analysis}

For a more complete disclosure of the problem of this study, the sources base must be divided into two periods. The first is written materials, images, schemes of settlements and drawings of dwellings compiled by European and Russian travelers and researchers of the 16th-18th centuries, the analysis of which will help to identify the prerequisites for the vernacular architecture emergence of the Kabardians in the 16th-18th centuries, to determine the main vectors of its development. The second is information from pre-

\footnotetext{
*Corresponding author: f.kanokova@mail.ru
} 
revolutionary authors and contemporaries, photographs and factual material presented in museum and private collections, the analysis of which will help to identify the features of the vernacular architecture of the Kabardians in the 19th - early 20th centuries.

In the XVI century the Italian ethnographer D. Interiano in the monographic description of Circassia, noted the features of the settlements and dwellings of the Kabardians for the first time [10]. At the end of the XVI century, we find similar information from the prominent Polish statesman M. Bronevsky, who included in the "Description of Tataria" a small section devoted to the Kabardians [3]. In the XVII century the monk of the Dominican order D. Lucca described the turbulent technology of making dwellings and defensive hedges, which Kabardians surround their houses with in order to protect them from enemies [14].

Information from Russian sources and rare Western European publications were collected in an essay by a statesman of the 18th century N. Witsen. Highlighting one of the characteristic features of the folk architecture of the Kabardians - the presence and location of the sacred hearth, the author pointed out - "... The hearth is in the middle of the house, and for those (Adygs - K.F.) who live closer to the sea, in the corner" [7]. Of particular interest are the published memoirs of the officer P.G. Bars. As a participant in the Persian campaign of Peter I, he had the opportunity to get acquainted with the eastern part of Circassia, i.e., to leave the data about its inhabitants, their dwellings, clothes, customs and religion with Kabarda and from personal observations [6]. In the first half of the 18th century the manuscripts of another participant in the campaign of Peter I - I.G. Gerbera were published. From the text translated from the German original, it follows: "The Circassians live in the Kabardian land, which is divided into Upper and Lower. Upper Kabarda borders on Tavlistan (Dagestan - K.F.), Avars, Georgian mountains, Kuban Tatars. Lower Kabarda stretches from the foothills of the Upper Kabarda to the Terek and Sunzha rivers ... Upper Kabarda ... does not have a single city and not a single real village; everyone who lives in the valleys between the mountains, where he likes, builds a small hut from reeds or a house from dried pieces of clay ... In Malaya Kabarda ... there are also few villages "[8]. Gerber's contemporary, French consul K. Glavani, in his work "Description of Circassia", divided Circassia into beyliks (districts - K.F.), singled out Kabarta (Kabarda K.F.) and Kuchuk-Kabarta (Small Kabarda - K.F.). Noting the districts' position and the number of dwellings, the author pointed out: "The last district in the eastern direction is called Kabarta ... wider and more powerful than all the others; it has 300 dwellings and many nobilities, under the control of one bey. To the Kalmyk side is the Kuchuk Kabarta (Malaya Kabarta) district ... it has one bey and 400 dwellings" [9].

At the end of the 18th century Russian academician, scientist-encyclopedist P.S. Pallas, in the framework of academic expeditions to the North Caucasus, collected very valuable information about the settlements and dwellings of the Kabardians. "The Circassians in general and the Kabardians in particular inhabit the villages, which they leave after a certain period of time, either due to clogging, or due to lack of sufficient security; then they take away the forest prepared for construction and household property, burning the rest the author writes, noting further - they then look for a convenient place for settlement ... They build their houses close to one another, in one or more circles or quadrangles, in such a way that the internal space is a common barnyard with only one gate, and the houses surrounding it serve as if to guard it. The house of the uzden (or prince), usually standing alone, contains a series of separate quadrangular rooms, two sazhen in size, where guests are accommodated ... Lavatories, scattered in the field, dug in the ground under clay huts of a round shape ... The houses are elongated quadrangles from 4 up to 5 fathoms in length and slightly more than one and a half fathoms in width, braided from branches, thickly coated with clay. The roofs are flat, made of lightweight rafters and covered with reeds. Each house consists of a large room for women and an adjoining a room for slaves and 
girls. One of the doors of the room faces the street; the other, located in one of the corners to the left of the entrance, overlooks the courtyard. Inside, near the front wall, there is a wicker and clay-coated hearth with a chimney and a short pipe ... A man usually lives in a separate room" [19].

The tradition of arranging buildings in a circle, noted above in written sources, is also recorded in a number of images. One of the valuable sources is a pencil drawing (Figure 1) and a plan of the Adyghe settlement made at the end of the 17th century. French merchant Zh-B. Tavernier. Analyzing the images, it can be noted that the houses, consisting of one or two rooms, were lined up in a circle, and the wall of one dwelling was the wall of the next one. Each dwelling had a wall hearth. There were also rooms for guests. In the center, along the radius, premises were built, perhaps they had the function of outbuildings or were a place for keeping animals. There is a well at the central entrance. We went for water through a small door opposite the main entrance.

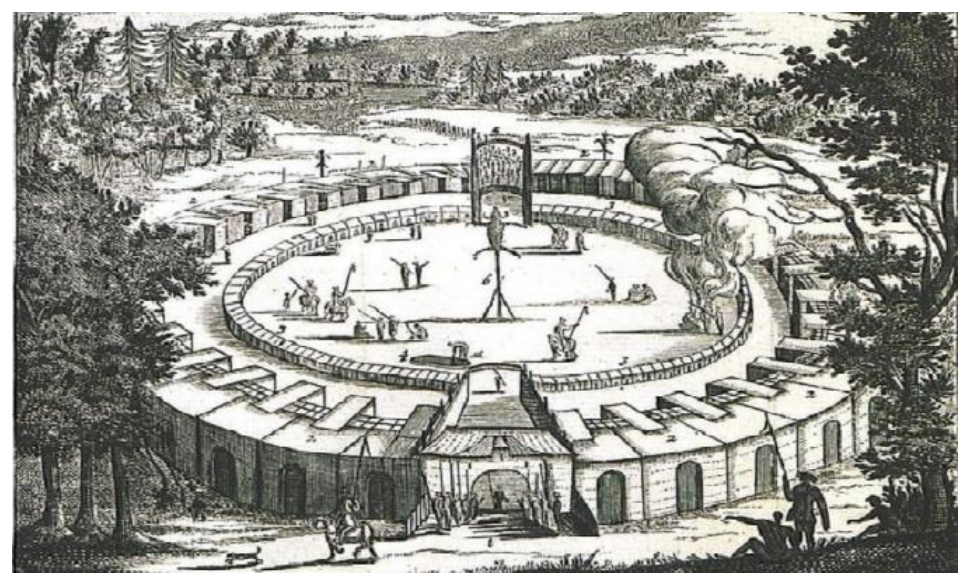

Fig. 1. Circassian village. Illustration from the book by Zh.B. Tavernier "Six Voyages of JeanBaptiste Tavernier, Baron de Aubon's squire to Turkey, Persia and India over forty years." Paris, $1681[22]$.

The circular arrangement of the Kabardians' houses was noted at the beginning of the 19 th century by the Russian academician G. Klaproth, who visited a number of districts of Kabarda. The author points out that "... they (the dwellings of the Kabardians - K.F.) are completely similar to the houses of the Kumyks. Woven from willow twigs coated with clay outside and inside. They differ from the Kumyk ones only in the roof, which is covered with thatch, since the clay in the country of the Circassians is preserved for a short time. Forty or fifty houses, usually located in a circle, form the village "kuadzhe" or "tavern", in the middle of which cattle are herded at night, and in the event of an attack, all those unable to bear arms are placed there. Outside the circle, at a distance of twenty-five steps, there are huts that serve as latrines" [11].

Klaport's contemporary, the Polish traveler J. Potocki, describing his trip to Kabarda, more precisely, a visit to Prince Shabas-Geriy, noted a different arrangement of the Kabardians' dwellings: "Their dwellings are not, in the full sense of the word, houses; rather, they are large baskets made of carefully woven twigs, plastered with clay on top and covered with a reed roof. Their general appearance is pleasant; they are in a row, surrounded by fences ... there are separate guest rooms. Such a village remains in one place for no more than four to five years" [20]. The Hungarian scientist Zh-Sh de Bess who, in addition to describing the Kabardian villages, paid attention to the description of Nalchik and the school that he saw in 1829 , also left valuable information. The author brought these descriptions into a separate chapter: “... Leaving Chegem behind us, we saw a beautiful 
valley in front of us; it was revived by Kabardian villages located close to each other, among them the village in which Murza-Missaost lived had a completely European look; the houses in it were built better than is usually seen among the Circassians ... I asked him (Prince-K.F.) why the foremen of the nationalities did not stand out for more comfortable, more spacious dwellings ... he answered me that these are the customs ... In this fort the Russian government ordered to build a school..." [2]. Social equality in the construction of dwellings is also noted in the work of S.M. Bronevsky. "Houses (huts) are built in an oblong quadrangle, at the corners there are pillars connected by crossbeams, in the middle there is a fence coated with clay outside and inside, a roof that is thatched or made of reeds ... This is the dwelling of the First Prince, like the poorest subject ...". The author also notes that the courtyards had a quadrangular shape and were fenced off from each other with a wattle fence. Inside the courtyard there were "three sections: the master's, the women's and the living room (or kunatsky). In the villages, the courtyards were widely spaced among themselves and did not make up decent streets ... At the two ends of the village, watchtowers were made of wattle fence, in which the inhabitants stood guard in turn. When a lot of manure accumulates in the village, they move from one place to another to avoid uncleanness" [4]. We find similar data in the descriptions of the dwellings of the Kabardians, compiled in 1833 by Lieutenant General of the Russian Service I.F. Blumberg [5].

From the information presented above, we see that until the middle of the XIX century. in the arrangement of dwellings and their construction, the Kabardians adhered to certain traditions. But, already from the end of the 19th century, as a result of the conquest of the Caucasus and the development of capitalist relations, radical changes are taking place in the house-building culture of the ethnic group - for example, the analysis of museum photographs, photographs recorded by M.G. Orkvasov [18] and the data of fundamental research of specialists of the XX century. on the material culture of the Kabardians - E.N. Studenetskaya [21], V.P. Kobycheva [13], G.Kh. Mambetov [15], allows us to note that, at the beginning of the XIX century, everywhere, there were single-chamber houses "uneshue", and already at the end of the XIX century. the most common types of dwellings were two-chamber and then multi-chamber houses.

The material of A.A. Miller, published in 1914 in the article "Circassian buildings" [16]. Russian archaeologist, ethnologist, artist and museum expert, at the beginning of the twentieth century. carried out a huge work on collecting and preserving material on the traditional architecture of the peoples of the Caucasus, including the Circassians. In the course of archaeological exploration from 1907 to 1916, Miller collected material, very valuable for this research - photographs and sketches of all stages of construction of dwellings and outbuildings of the Circassian estate, as well as a number of elements of their construction, which are now kept in the Russian Ethnographic Museum.

When conducting a comparative analysis, in order to identify the distinctive features of the folk architecture of the Kabardians, pictorial and written sources were also used on the folk architecture of neighboring ethnic groups $[1,12,13]$.

\section{Main part}

The results of the analysis of sources make it possible not only to study the features of the vernacular architecture of the Kabardians, but also to identify certain stages of its formation. As noted above, the extreme point of the first stage can be considered the 18th century, when the estates of the Kabardians were located in a closed circle or square, had a common area and a cattle yard. The second stage, studied within the framework of the stated chronology, is the 19th - early 20th century. - when, under the influence of the colonial policy of tsarism, the fortifications were liquidated, fundamental changes took 
place in the house-building practice of the Kabardians and the estates began to be arranged randomly. The entire manor complex of the period under review was a fenced-in courtyard with residential and outbuildings. The main one was considered to be a residential courtyard, on which the building in which the family lived was located - it was, initially, a single-chamber tourluch house of an oblong shape with semi-oval ends and a hipped roof covered with thatch. "The dwellings of the Circassians are very simple and lightweight; their houses - "huts" - are built in the form of a parallelogram, at the base of which there are thick pillars tied together by crossbars, and between them the space is covered with wicker walls, which are coated on both sides; the roof is made of straw or reeds" - this is how I.F. Blamberg [5].

Until the middle of the XIX century the houses did not have foundations and windows; light entered the room through the front door and smoker. During the same period, singlechamber houses with a hearth served as a bedroom, kitchen and dining room. The house space was strictly zoned - the hearth was considered the central and sacred place of the dwelling, in which not only food was prepared, but also the rituals of the family cycle were performed. The right side of the room was for men, there was a trestle bed - a place for the head of the family or a guest of honor. The left side was for women, where everything that was included in the economic management of a woman was located. Similar zoning principles in the same period were characteristic of the spatial organization of the familywide yurt for an ethnic group adjacent to the Kabardians - the Nogais [12]. Since the second half of the XIX century single-chamber houses have started to be replaced by two-chamber ones. The layout and location of entrances to two-chamber houses in different estates differed. In one case, these are premises with one entrance and an adjacent door, in the second, the premises with two separate entrances, in the third, these are premises with two entrances and an adjacent door. Usually, a family of parents and a married son lived in a two-chamber house. As the family grew, additional rooms started being added to the house. So, according to the photographs of the late XIX-early XX century, it is possible to observe the transformation of a single-chamber dwelling into a multi-chamber one. The dwelling could be "extended" by attaching up to 14 rooms to it. This is how the "long house" traditional for Kabardians was formed (Figure 2).

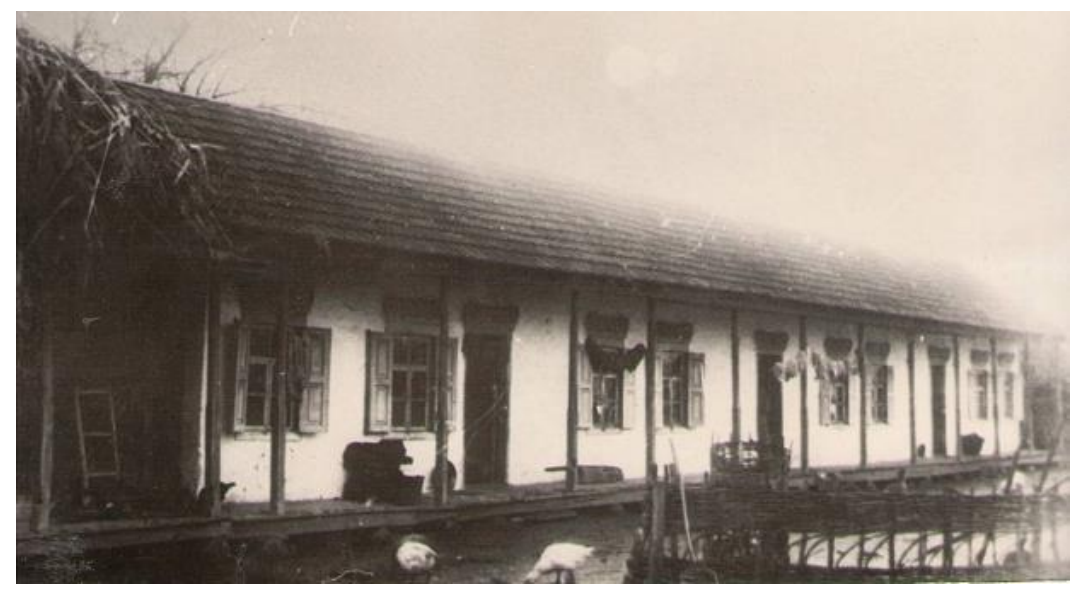

Fig. 2. Multi-chamber house of Kabardians. End of the 19th century

Illustration from the book of M.M. Orkvasov "Materials on the architecture of Circassian dwellings." Nalchik, 2011 [18].

Despite the changes taking place in the house-building practice of the Kabardians, when planning the house, the location of the place of honor remained unchanged. During the 
construction of a two-chamber house with one entrance, the adjacent door that led to the master's room was always on the right. In multi-cell buildings, this room was always the first to the right and the house "built up" from it to the left. It was in this room that the hearth was located. Closer to the entrance to the house, there was a guest room. According to the researcher of the history and culture of the Circassians Z.M. Naloeva: "The guest house played a huge social role in the life of Kabardians" [17]. A distinctive feature of the Kabardian estate of E.N. Studenetskaya considers "the presence of a separate kitchen in it. Scientists associate this with the habit of avoidance. The dwellings of servants adjoined the kitchen, in the estates of the princes" [21].

If at the beginning of the XIX century window openings in the dwellings of Kabardians were practically not built, then already at the end of the 19th century the houses even had glazed windows, often closed by shutters with plat bands. As G.Kh. Mambetov states: "At the same time, a second door appears in the hallway, which served to allow women to enter the garden ... On the front side of the house, a small canopy was built along its entire length, which, with the appearance of the foundation, turned into an open gallery" [15].

At the beginning of the twentieth century significant changes have taken place in the construction practice of the Kabardians. Houses began to be erected from adobe or burnt bricks, the roof was covered with tiles and even tin. In the villages, dwellings of a new, Russian type started to be spread, differing from the traditional ones not only in form, but also in layout.

\section{Conclusion}

Thus, having considered the ways of the house-building practice development of the Kabardians in general and the features of the vernacular architecture of the 19th - early 20th centuries in particular, a number of conclusions can be drawn:

1. Until the beginning of the twentieth century Kabardians used a single material and technology for the construction of a tourluch house This wellestablished tradition was associated primarily with the availability of building materials.

2. One of the signs of vernacular architecture is the presence of a focus. During the period under review, the hearth not only did not lose its main function, but also retained its sacred significance in the house.

3. Despite the change in the dwelling shape and the increase in its area due to the premises' additions, the master's room remained the main, one might say, the main room. Its location also remained unchanged - namely, the "right" side - the side of the head of the family. This feature is noted both in a two-chamber dwelling with one entrance and an adjacent door, and in multi-chamber.

4. In the planning of the estate of the XIX - early XX century, as well as in the residential complexes of the XVI-XVIII centuries it was necessary to take into account the presence of a separate guest house or a separate room for receiving guests.

All of the above-listed features persisted both during the period preceding the chronology declared in the research topic, and up to its end point, i.e., before the beginning of the twentieth century. 


\section{References}

1. E.B. Bernstein, Architecture of the Balkarian People's Dwelling ("Dixie", Moscow, 1993) $160 \mathrm{p}$.

2. Bess Zh-Sh, Adygs, Balkars and Karachais in the news of European authors of the XIII-XIX centuries. (Elbrus, Nalchik, 1974)

3. M. Bronevsky, Adygs, Balkars and Karachais in the news of European authors of the XIII-XIX centuries. (Elbrus, Nalchik, 1974)

4. S.M. Bronevsky, The latest geographical news about the Caucasus: Part II (Printing house of S. Silivanovsky, Moscow, 1823)

5. I.F. Blamberg, Topographic, statistical and military description of the Caucasus. (ElFa, Nalchik, 1999)

6. Brus P-G, Adygs, Balkars and Karachais in the news of European authors of the XIIIXIX centuries. (Elbrus, Nalchik, 1974)

7. N. Witsen, Adygs, Balkars and Karachais in the news of European authors of the XIIIXIX centuries. (Nalchik: Elbrus, 1974)

8. L. Gerber, Adygs, Balkars and Karachais in the news of European authors of the XIIIXIX centuries. (Elbrus, Nalchik, 1974)

9. K. Glavani, Adygs, Balkars and Karachais in the news of European authors of the XIIIXIX centuries. (Elbrus, Nalchik, 1974)

10. D. Interiano, Adygs, Balkars and Karachais in the news of European authors of the XIII-XIX centuries. (Elbrus, Nalchik, 1974)

11. Klaproth G-Yu, Adygs, Balkars and Karachais in the news of European authors of the XIII-XIX centuries. (Elbrus, Nalchik, 1974)

12. F.Y. Kanokova, Materials and Tehnologies in Construction and Architecture: materials Science Forum, Switerland 931, 733-739 (2018)

13. V.P. Kobychev, Settlement and dwelling of the peoples of the North Caucasus in the XIX-XX centuries. (Science, Moscow, 1982)

14. D. Lucca, Adygs, Balkars and Karachais in the news of European authors of the XIIIXIX centuries. (Elbrus, Nalchik, 1974)

15. G.H. Mambetov, Traditional culture of Kabardians and Balkars (Elbrus, Nalchik, 2013)

16. A.A. Miller, Materials on the ethnography of Russia (St. Petersburg, Leningrad) II, 57 - 78 (1913)

17. Z.M. Naloev, From the history of culture of the Circassians (Elbrus, Nalchik, 1978)

18. M.M. Orkvasov, Materials on the architecture of Circassian dwellings (Tetragraf, Nalchik, 2011)

19. Palace P-S, Adygs, Balkars and Karachais in the news of European authors of the XIIIXIX centuries (Elbrus, Nalchik, 1974)

20. Ya. Potocki, Adygs, Balkars and Karachais in the news of European authors of the XIII-XIX centuries. (Elbrus, Nalchik, 1974)

21. E.N. Studenetskaya, Modern Kabardian dwelling, Soviet ethnography: №4 (Publishing house of the Academy of Sciences of the USSR, Moscow, 1948)

22. Tavernier J-B, Six voyages of Jean-Baptiste Tavernier, squire of Baron de Aubon, to Turkey, Persia and India for forty years (Paris, 1681) 